\title{
Presidents, Parties, and the Business Cycle, 1949-2009
}

\author{
MICHAEL COMISKEY \\ Penn State Fayette \\ LAWRENCE C. MARSH \\ University of Notre Dame
}

\begin{abstract}
Scattered works by political scientists since the 1970s have reported that Democratic presidents have compiled stronger economic records than their Republican counterparts: economic growth has been higher, unemployment lower, and inequality has fallen during Democratic administrations while the opposite outcomes have occurred under Republican presidents. Recently, however, Campbell has vigorously challenged these findings. This article reexamines the data for 1949-2009 using new methods and measures, and confirms the earlier findings for unemployment and real gross domestic product (GDP).
\end{abstract}

A small body of research since the 1970s has reported that Democratic presidents have compiled better economic records than their Republican counterparts in the post-World War II era (Alesina and Rosenthal 1995; Bartels 2008; Hibbs 1977, 1987). Bartels' 2008 book Unequal Democracy has understandably been the most prominent of these works. In a seeming tour de force in political economy, Bartels finds that under Democratic presidents U.S. gross national product (GNP) and family incomes have grown faster, unemployment has been lower, and economic inequality has fallen, while the opposite and less favorable outcomes have characterized Republican administrations (Chapter 2). If correct, these results pose a conundrum for theories of retrospective voting by rational voters in presidential elections: if the economy has performed better under Democratic presidents, why have Republicans won nine of the 15 U.S. presidential elections since 1952? Bartels' provocative and disturbing response is that Republicans have fared so well because structural factors and failures by American voters to behave rationally have produced "partisan biases"

Michael Comiskey is associate professor of political science at the Penn State Fayette Campus in Uniontown, PA. $H$ is research has focused on welfare policy in the advanced democracies, the effects of Reaganomics, and presidential Supreme Court nominations.

Lawrence C. Marsh is professor emeritus of economics at the University of Notre Dame. He has published widely and has served as guest editor for the Journal of Econometrics. 
that permit Republican presidential candidates to escape accountability for their party's relatively poor record of economic management (Chapter 4).

More recently, however, Campbell (2011) has vigorously challenged the finding that Democratic presidents have overseen better economic performances than Republicans. Taking particular exception to Bartels' work, Campbell has argued that every new Republican administration in the years from 1948 to 2005 (the period of his and Bartels' studies) had to contend with a recession left to it by the preceding Democratic administration, while each new Democratic administration in that period inherited a healthy, growing economy from its Republican predecessor. He also claims that previous studies have failed to control adequately for the considerable inertia of the U.S. economy, with economic performance in a year depending heavily on economic performance in the period leading into that year. Once these factors are properly controlled for, Campbell contends that "party differences in economic performance are shown to be the effects of economic conditions inherited from the previous president and not the consequence of real policy differences" between the parties (Campbell 2011, 1). If so, Bartels' conundrum disappears: Republicans have succeeded in presidential elections because they have managed the economy at least as well as the Democrats.

We agree with Campbell that studies of the relationship between the president's party and economic performance must control for the portion of the business cycle that is, or may well be, outside the president's control, but we have reservations about Bartels' and especially Campbell's methods for doing so. We therefore analyze the impact of presidential partisanship on economic output, income, and unemployment while controlling for the phase of economic activity with new methods and measures.

The next section explores the Bartels-Campbell controversy in more detail. It also discusses some difficulties that arise when attempting to identify the impact of presidents on the economy while simultaneously controlling statistically for the portion of the business cycle that presidents cannot be expected to influence. The following section presents our preferred methods and the penultimate section provides our results, which generally confirm the findings of Bartels and others that economic output and its growth were higher, and unemployment lower, under Democratic administrations. The final section analyzes the implications of these findings and suggests alternative hypotheses for the Democrats' difficulties in presidential elections.

\section{Controlling for the Business Cycle}

Bartels' (2008) principal finding was that annual growth in the real incomes of most American families was significantly higher under Democratic presidents than during Republican administrations between 1948 and 2005. The positive relationship between income growth and Democratic presidencies held for both pre- and posttax incomes and after controlling for exogenous factors such as changes in oil prices and labor force participation rates (Chapter 2).

Of particular interest was the distributional pattern of income gains under Democratic presidents. The biggest gains from a Democratic presidency accrued to the lower 
income strata, with families at the 20th percentile of the income distribution gaining a whopping 2 to $3 \%$ more income annually from having a Democrat in the White House; families at the 80 th percentile gained an additional 1 to $1.5 \%$ per year from a Democratic presidency. Only for incomes at the 95th percentile was the variable for Democratic control of the White House insignificant in a statistical sense, though even families at that high level appeared to gain about $0.5 \%$ more income annually under the Democrats. This differential pattern of income growth implies that income inequality fell during Democratic administrations (when the poor gain income faster than the affluent, inequality falls) and that inequality rose during Republican administrations (nearly everyone's income rose more slowly under the Republicans, but low-income families did especially poorly).

If incomes rose faster across the board or very nearly so during Democratic administrations, the economy must have grown faster under the Democrats as well, and so Bartels found: after controlling for other factors the real per capita GNP rose about 1.1 percentage points faster each year under Democratic presidents, and the unemployment rate was lower by about 1.4 percentage points (Bartels 2008, 50, 48). And finally, there was no clear evidence that Democratic presidents engendered any more price inflation than their Republican counterparts, despite coaxing more growth from the economy. ${ }^{1}$ The obvious upshot of these results is that the U.S. economy performed much better during Democratic administrations, whose economic policies Bartels infers to have been superior to those of Republican administrations.

Bartels derived these results by employing two different types of lags. First, he assumes that a new president cannot significantly influence the economy in his first year in office because it takes time for new policies to be enacted and exert their effects on the economy. His presidential partisanship variable is therefore measured "from one year following [a new president's] inauguration to one year following [the] subsequent inauguration" (Bartels 2008 32, 37, etc.) Second, Bartels' models include among the regressors the dependent variable lagged one period (one year), presumably in the belief that the economy displays inertia and that economic performance in one year is partly a function of economic performance in the previous year.

Campbell (2011) likewise excuses presidents from responsibility for the economy in their first year in office. But he claims that for later years, the proper control for economic inertia is not performance in the prior year, but rather performance in the last two quarters of the prior year. He notes by way of example that the correlations between real GNP growth in a year and real GNP growth in the third and fourth quarters of the prior year are .58 and .56 , while the correlation is much weaker (.35) between annual GNP growth and the same variable in the first two quarters of the prior year. Campbell therefore concludes that "Perhaps what happened a full year ago or nine months ago does not matter to economic growth today, but economic conditions in the preceding couple of quarters might well be important to current economic conditions" (Campbell 2011, 11).

1. Bartels did find "some statistical evidence of higher inflation rates under Democratic presidents" in analyses he reports in shorthand form $(200849 \mathrm{n} 36)$. We discuss the possible electoral import of this finding in our concluding section. 
TABLE 1

Economic Conditions at Start of Administrations

\begin{tabular}{lccccc}
\hline $\begin{array}{l}\text { Democratic to } \\
\text { Republican }\end{array}$ & $\begin{array}{c}\text { Election } \\
\text { Year }\end{array}$ & $\begin{array}{c}\text { Date } \\
\text { Inaugurated }\end{array}$ & $\begin{array}{c}\text { Unemployment Rate } \\
\text { Month of Election }\end{array}$ & $\begin{array}{c}\text { Inflation (CPI) } \\
\text { in Election Year (\%) }\end{array}$ & $\begin{array}{c}\text { Quarters Since } \\
\text { Last Trough }\end{array}$ \\
\hline Eisenhower & 1952 & $1 / 53$ & 2.8 & 0.9 & 13 \\
Nixon & 1968 & $1 / 69$ & 3.4 & 5.9 & 32 \\
Reagan & 1980 & $1 / 81$ & 7.5 & 12.4 & 3 \\
G.W. Bush & 2000 & $1 / 01$ & 3.9 & 3.4 & 40 \\
Mean & & & 4.4 & 5.7 & 22 \\
Republican to Democratic & & & & & 0 \\
Kennedy & 1960 & $1 / 61$ & 6.1 & 5.4 & 8 \\
Carter & 1976 & $1 / 77$ & 7.8 & 3.0 & 8 \\
Clinton & 1992 & $1 / 93$ & 7.4 & 0.0 & $0 *$ \\
Obama & 2008 & $1 / 09$ & 6.8 & 2.4 & 4 \\
Mean & & & 7.0 & 3.7 & 20.2 \\
Mean for 1949-2009 & & & 5.8 & & \\
\hline
\end{tabular}

* Recovery began five months after Obama's inauguration.

And his statistical analyses show that "once the lagged effects of the economy in the six months leading into a year are taken into account, there are no significant differences in the records of Democratic and Republican presidents with respect to economic growth, unemployment, or income inequality" (Campbell 2011, 15).

We agree with Campbell that the analysis must include some control for the phase of economic activity. For the eight transitions from one party to the other in the years 1949-2009, Table 1 presents data on consumer price inflation in the election year, the unemployment rate on election day, and the number of quarters between the last trough of economic activity (the end of the most recent recession) and the new president's inauguration. The bottom line shows that unemployment averaged 5.8\% annually, and inflation averaged $3.7 \%$ per year over the entire $1949-2009$ period, while the average economic expansion in the period lasted 20.2 quarters.

While generalizations are normally hazardous with such a small $n$, two striking patterns emerge. First, the nation switches from Republican to Democratic presidents at times of above-average unemployment $(7.0 \%)$ and below-average inflation $(2.4 \%)$, and from Democratic to Republican presidents at times of high inflation (5.7\%) and low unemployment (4.4\%). Second, the nation inaugurated new Democratic presidents early in economic expansions - an average of four quarters into an expansion-when the economy was on an upswing. ${ }^{2}$ New Republican presidents, by contrast, took office an average of 22 months into an economic expansion. With the average economic expansion in this period lasting 20.2 quarters (National Bureau of Economic Research [NBER]

2. Technically, President Obama took office 29 quarters after the previous trough in November 2001. But as the economy at the time of his inauguration had been deep in recession for over four quarters and would officially emerge from recession less than two quarters later in June 2009, we think it more accurate to place his inauguration at the start of a recovery rather than in the late stages of an expansion. We therefore assign him a zero value. 
2011), the average new Republican president took office just when a recession might be expected. And each of the four new Republican administrations in the upper panel of Table 1 did in fact experience a recession during its first year in office (NBER 2011).

If "most economists" are correct in their belief that the monetary policies of the Federal Reserve Board exert a powerful influence over the peaks and valleys of economic activity (Romer 2008, 50) and that monetary policy works with a lengthy lag (Bernanke and Gertler 1995; Gordon 2009, 459-60), then Campbell is correct: new Republican presidents bore little responsibility for the recessions that followed quickly upon their inaugurations. Even if newly minted Republican administrations welcomed or at least tolerated these recessions as an antidote to inflation, these slowdowns were "in the works" at the time of their inaugurations and almost certainly would have occurred anyway as a result of Federal Reserve policies.

The question of how to analyze economic performance in period $t$ while controlling for the economy's inertia leading into that period is a difficult one. Inertial effects must be adequately controlled for, but to the extent economic performance in period $t$ reflects the inertial effects of economic performance in period $t-1$, controlling for the inertial properties of the economy by following the common practice of using a lagged value of the dependent variable runs a risk of controlling for the dependent variable itself.

Bartels' (2008) statistically significant results for party of the president and other variables indicate that he avoided overcontrolling for economic inertia, although his shorthand report of his results leaves open the possibility that he undercontrolled for inertia (50). And Campbell's (2011) initial reanalysis of the annual economic growth rate, which controls for growth in the previous year as Bartels did, finds no significant relationship between GNP growth in year $t$ and growth in year $t-1$ (9-11). As Campbell has argued, this result suggests that as a control for growth in year $t$, growth in year $t-1$ may not adequately capture the inertia of the economy, and that Bartels may therefore have undercontrolled for that inertia.

Campbell (2011) then found strong effects for lagged values by analyzing economic performance in year $t$ while controlling for economic growth in the last two quarters of year $t-1$. And the inclusion of these lagged values vitiates all statistically significant relationships between favorable economic outcomes and Democratic presidencies $(10,13,14)$.

But the risk of controlling for the dependent variable grows with the strength of the correlation between the dependent variable and its lagged values, and the correlations between economic growth in year $t$ and growth in the last two quarters of year $t-1$ are a fairly robust .58 and .56 , with associated probability values less than $.0001 .^{3}$

Campbell recognizes this danger and offers two reasons why it is not a problem in his view: "First, the lagged GNP data encompass a half-year of independently measured economic activity. Second, the correlations between these lagged GNP quarters and the following annual GNP measure indicate a fair degree of independence. Real GNP growth

3. Calculation of these probability values is possible because Professor Campbell has made his data publicly available at http://www.acsu.buffalo.edu/ jcampbel/ (accessed December 15, 2011). 
in a year is correlated at .56 with the prior year's fourth quarter and .58 with the prior year's third quarter growth" $(2011,11 \mathrm{n} 7)$. The fact remains, however, that (1) the two things being measured are not independent of each other and (2) Campbell elsewhere relies on the very strength of these correlations to justify their use as controls (10-11).

For these reasons, it may be preferable to control for economic inertia by using measures of time rather than lagged values of the dependent variable.

\section{Methods and Measures}

We use time in three ways to assess the impact of presidential partisanship on economic performance while attempting to control for the autonomous component of the business cycle. First we compare the levels of real gross domestic product (GDP) growth and unemployment in the second terms of Republican presidents with their levels in other years. If Republican presidents only seem to preside over sluggish economies because they inherit recessions from their Democratic predecessors, economic performance should be better in their second terms than in their first, as the economy has had time to recover by then. For all four of the Republican presidents who followed a Democrat in office during the 1949-2009 period (Eisenhower, Nixon, Reagan, and George W. Bush), the recession that began in their first year was over by their $22 \mathrm{nd}$ month in office. By the time of their second terms, the conditions they inherited on taking office were a thing of the past.

Our second and third methods of controlling for the business cycle involve multiple regression analyses with two alternative sets of dependent variables, two sets of economic control variables, and two different regression techniques. First, we hypothesize that the growth rates of real GDP and real disposable personal income per capita vary in a systematic way over the course of a business cycle. As the economy moves from one trough of economic activity to the following trough, the rate of economic growth generally falls, changing from positive in the upswing after a trough, to zero at the next peak of economic activity, to negative in the downswing before the next trough. Similarly, as the economy moves from one peak of economic activity to the subsequent peak, the rate of growth generally rises, going from negative in the downswing following a peak, to zero just before the economy rebounds, to positive in the upswing before the next peak.

We therefore regress the percentage growth of real GDP and real disposable personal income per capita on two economic control variables, QTROUGH and QPEAK, which express the number of quarters since the most recent trough and most recent peak of economic activity, respectively. We expect QTROUGH to have a negative coefficient, as the rate of economic growth is hypothesized here to generally decline from one trough of economic activity to the next, going from positive in the upswing following a trough to negative as the economy approaches the subsequent trough. We expect QPEAK to have a positive coefficient, as the rate of economic growth is hypothesized to generally rise 


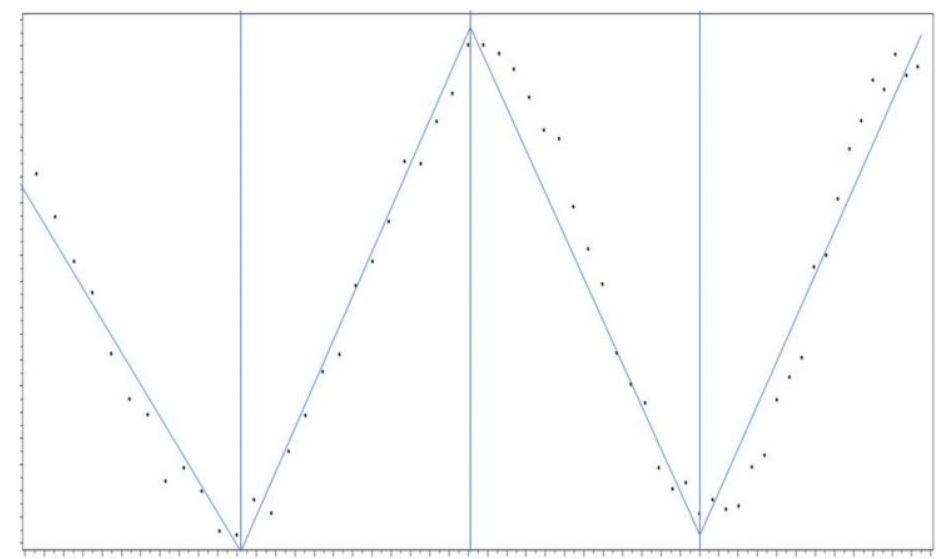

FIGURE 1. Hypothetical Spline Regression Line.

from one peak of economic activity to the following peak, ${ }^{4}$ going from negative in the recession that follows a cyclical peak to positive in the subsequent rebound.

To generate the rates of change that we analyzed, we used quarterly data on real GDP and real disposable personal income per capita from 1949:1 to 2009:4 to calculate the percentage change in these variables from each quarter to the period that is four quarters later, generating 240 observations: $1949: 1$ to $1950: 1$, 1949:2 to 1950:2 . 2008:4 to 2009:4. This method quadruples the number of observations as compared with using annual data and reduces the random variation present in quarterly data on economic growth. ${ }^{5}$

Our other method of controlling for the phase of the business cycle via regression is to perform linear "spline" regressions on the levels of real GDP, real disposable personal income per capita, and the civilian unemployment rate. With time as an independent variable, spline regression (Marsh and Cormier 2002) produces a different regression line with a different slope for each subperiod of the period under study.

Figure 1 shows a hypothetical spline regression line (Marsh and Cormier 2002, 14). The dots show the hypothetical observed data points while the solid line shows hypothetical predicted values from a spline regression. Each subperiod of growth and decline has a different slope, which the spline regression captures. In our analyses, as here, the spline regression line for the entire period is restricted to be continuous: the regression line for each subperiod must join the line for the preceding and following subperiods.

4. We admittedly ignore the very early phase of an economic expansion, when growth may be positive but slow, and the very last stage just before a trough when growth is still negative but rising toward zero, as well as the periods immediately before and after peaks. We believe the results reported below justify this stylized approach.

5. An anonymous reviewer has expressed concern that we induced autocorrelation by generating the dependent variables this way, but we did not do so. Although the observations overlap in time, each quarterly datum is used only twice, as the end point of one period and the start of another. The timing of change in the dependent variable between the start and end of a period does not matter, and hence there is no overlap between the observations in a statistical sense. Dependent variables of this sort are commonly analyzed in the economics and finance literatures. As explained below, we did correct for autocorrelation inherent in the data. 
We use the start and end dates of recessions between 1949 and 2009, as determined by the NBER (2011), as the start and end dates for our subperiods. In the spline regressions, the estimated coefficient on the variable for each subperiod represents the rate of change in the dependent variable in each economic expansion and contraction between 1949 and 2009, while the estimated coefficient for the presidency variable represents an upward or downward shift of the regression line during Democratic and Republican administrations. We do not use the variables QTROUGH and QPEAK in these spline regressions, as the two of them, and the spline technique with its specified subperiods, are alternative ways of controlling for the business cycle. ${ }^{6}$

We agree with Campbell and Bartels that presidents cannot normally be expected to influence the economy in their first year in office. For six of the 11 presidencies from 1949 to 2009, no major new fiscal policy initiatives were enacted in their first six months in office (Romer and Romer 2008; Yang 2009), so any fiscal impact they had began after that. For the other five presidents, the median lag between their inauguration and the enactment of their proposed measures was five months. Another lag then arose because some of the measures enacted took effect months after their enactment such as the "major parts" of President Clinton's 1993 deficit reduction package that took effect in January 1994 (Romer and Romer 2008, 81). An "effectiveness lag" then ensues between implementation of a fiscal policy and its impact on the economy. Spending changes generally have an impact quickly, with the "peak effect" coming as soon as one or two quarters after implementation (Elmendorf 2009, 1; Elmendorf and Reifschneider 2002, 381). But most presidentially initiated changes in fiscal policy have taken the form of tax changes, which have a longer effectiveness lag than changes in spending, perhaps four quarters for the peak effect in the case of tax cuts to spur aggregate demand and much longer lags for "supply-side" tax changes (Blanchard and Perotti 2002, 1345-46; Elmendorf and Furman 2008, 14-17).

In addition, much evidence points to monetary policy as a prime driver of the business cycle (Romer 2008). And changes in monetary policy require about a year and a half to have even half of their impact (Bernanke and Gertler 1995; Gordon 2009, 459-60). So a new president who influences the economy through monetary policy has a limited impact for his initial 18 months in office.

For these reasons we agree with Bartels (2008) and Campbell (2011) that a new president is likely to have little economic impact in his first year. We also agree with Campbell that "there is some period in which the effects of a current president considerably overlap with those of his predecessor" (2011, 4). A new president's responsibility for the economy does not switch on like a light at the end of his first year.

Our data set, consisting of successive and overlapping four-quarter periods, permits us to phase in gradually a new president's responsibility for the economy-in his second

6. We did not regress the unemployment rate on QTROUGH and QPEAK because the level of unemployment, unlike the growth rate of real GDP and real personal disposable income, does not bear the same sort of linear relationship to time that the growth rates do. The level of unemployment does not generally fall from one trough of economic activity to the next (it falls and then rises) and does not generally rise from one peak of economic activity to the next (it rises and then falls).

7. It is possible that economic actors alter their behavior in anticipation of enacted policies, but such a possibility is not in keeping with the economic literature on policy effectiveness lags. 
TABLE 2

Method of Coding Presidential Party Variable

\begin{tabular}{lc}
\hline Observation & Value of PRESIDENT \\
\hline $1952: 1$ to $1953: 1$ & 1 \\
$1952: 2$ to $1953: 2$ & 1 \\
$1952: 4$ to $1953: 4$ & 1 \\
$1953: 1$ to $1954: 1$ & .75 \\
$1953: 2$ to $1954: 2$ & .50 \\
$1953: 3$ to $1954: 3$ & .25 \\
$1953: 4$ to $1954: 4$ & 0 \\
$1954: 1$ to $1955: 1$ & 0 \\
\hline
\end{tabular}

year, as we think consistent with the history of policy actions early in presidencies and the economic literature on the lagged effectiveness of monetary and fiscal policies. Our measure for party of the president equals 0 for periods of full Republican responsibility for the economy and 1 for periods of full Democratic responsibility, with intermediate values during transitional periods (the second year after a president of one party replaces a president of the other party). For the January 1953 handoff from Democrat Harry Truman to Republican Dwight Eisenhower, for example, Table 2 shows how our presidential party variable, PRESIDENT, is coded. A new president replacing someone of the opposite party does not bear full responsibility for the economy until the last quarter of his second year.

We also test variables, coded similarly, for the percentage of congressional seats held by Democrats, and dummy variables for all eight possible partisan combinations for control of House, Senate, and presidency.

Scholars since Nordhaus (1975) have tested the hypothesis that presidents manipulate the economy so as to maximize production and income gains in the period leading up to a presidential election. We test this hypothesis in two alternative ways. The first is with a dummy variable for all election years, ELECTION, which equals 1 for each four-quarter period ending in a quarter containing a presidential election, 1 in the preceding and following four-quarter periods, and 0 otherwise. The second way is with separate dummy variables, coded similarly to ELECTION, for "Republican" and "Democratic" election years (presidential election years with a Republican incumbent in the White House and those with a Democratic incumbent).

We test for the possibility that the levels and growth rates of output and income were higher, and unemployment lower, during the three most expensive wars of the 1949-2009 period: the Korean War (in quarters 1950:3-1953:3), the Vietnam War (quarters 1965:1 to 1972:4), and the Iraq War (beginning in 2003:1). In each instance, a dummy variable goes up in equal steps from 0 to 1 in the first four quarters of hostilities and declines in equal steps from 1 to 0 in the four quarters after the war's end (except the Iraq War, where U.S. combat involvement continued past the end point of our study).

We also control for the real price of oil, defined as the price of West Texas intermediate crude oil divided by the GDP deflator and lagged one year, as preliminary analyses indicated that this measure exerted the greatest impact on economic growth and unemployment of several alternative formulations. 
TABLE 3

Economic Performance by Year of Administration

\begin{tabular}{|c|c|c|c|c|}
\hline \multicolumn{5}{|c|}{ Real Gross Domestic Product Growth, Fourth Quarter to Fourth Quarter (\%) } \\
\hline & $1 s t$ & 2nd & $3 r d$ & 4 th \\
\hline Democratic Administrations & 3.52 & 6.27 & 3.51 & 3.75 \\
\hline Republican Administrations & 2.01 & 1.05 & 4.17 & 2.98 \\
\hline Difference & 1.51 & 5.22 & -.66 & .77 \\
\hline \multicolumn{5}{|c|}{ Average Annual Unemployment Rate (\%) } \\
\hline & $1 s t$ & $2 n d$ & $3 r d$ & $4 t h$ \\
\hline Democratic Administrations & 6.49 & 5.21 & 4.74 & 4.72 \\
\hline Republican Administrations & 5.05 & 6.20 & 6.39 & 6.09 \\
\hline Difference & 1.44 & -1.01 & -1.65 & -1.37 \\
\hline
\end{tabular}

In two ways our measures bias our tests somewhat against the hypothesis of a partisan difference in economic performance. First, we attribute all of a president's first-year record to his predecessor, as Bartels and Campbell did. But unlike them we also attribute half of a president's second-year record to his predecessor. As the top panel of Table 3 demonstrates, the largest difference by far in economic growth rates under Democratic and Republican presidents occurred in the second year of their administrations (see Alesina and Rosenthal 1995, 181; Bartels 2008, 52-53).

In our 1949-2009 period, there were seven Democratic inaugurations. In about half of these cases (four of seven), the Democratic president followed a Republican in office (1961, 1977, 1993, and 2009). By attributing these four Democrats' first-year performances to their Republican predecessors, we eliminate about half of the apparent Democratic advantage of 1.5 percentage points in first-year growth rates shown in the top panel of Table 3. By attributing one-half of these four Democrats' second-year records to their Republican predecessors, we shift to the Republicans about one-fourth (one-half times one-half), of the second-year Democratic advantage of 5.22 percentage points. The bottom panel of Table 3 implies that a similar but smaller redistribution of credit from Democrats to Republicans occurs when we, unlike previous authors, reallocate a quarter of the difference in unemployment (1 percentage point lower under the Democrats) in presidents' second years.

A second factor potentially suppressing significant results is that we, like previous authors, risk controlling for our own dependent variables. These measures - the unemployment rate and growth and levels of real GDP and real disposable personal income per capita-express the state of the economy in a broad sense. But so do our controls for the business cycle, QTROUGH, QPEAK, and the subperiods in our spline regressions, which are defined by the start and end dates of recessions. We thus run a risk of analyzing economic conditions while simultaneously controlling for them. But some risk of this sort may be inevitable if we are to investigate the very plausible claim that the two parties' economic records did not differ once the business cycle is properly controlled for. 


\section{Results}

Table 4 presents the results of $t$-tests for the difference between the mean annual rate of real GDP growth in Republican second terms $(2.43 \%)$ and various other years. ${ }^{8}$ The higher annual growth rate in Republicans' first terms $(3.59 \%)$ than in their second $(2.43 \%)$ seems to contradict the claim that Republican presidents compiled weak records on growth because they inherited weak economies from their Democratic predecessors, although the difference is not statistically significant even at the 10 level. Growth in Republican second terms was, however, significantly slower than it was in various categories of Democratic years and in all years that were not part of a Republican second term (probability values all $<.05$ ).

Table 5 presents the results for the difference between the mean annual rate of unemployment in Republican second terms (6.25\%) and various other years. Unemployment was virtually identical in Republican first and second terms (6.23\% and $6.25 \%)$. The unemployment rate averaged 1 to 2 percentage points higher in Republican second terms than in all other types of years; these results are all statistically significant at the .01 or lower level.

The comparisons in Tables 4 and 5 belie the claim that Republican presidents' records are unfairly tarnished by the poor economic conditions they inherited from Democrats. As unemployment was equally high in Republican first and second terms, and GDP growth was actually slower in their second terms than in their first, the inferiority of the overall Republican record on growth and unemployment cannot be attributed to conditions in Republican first terms.

Table 6 reports the results of regressions on the annual percentage growth of real GDP and real disposable personal income per capita (Models 1 and 2). Standard errors are in parentheses. The economic control measures are the number of quarters since the last trough and last peak of economic activity, QTROUGH and QPEAK. As preliminary results with Ordinary Least Squares indicated a high degree of positive serial correlation,

TABLE 4

Mean Annual Real Gross Domestic Product (GDP) Growth, 1949-2009

Republican Second Term Years $(2.43 \%)$ versus Other Years

\begin{tabular}{lcccc}
\hline & $\begin{array}{c}\text { Mean Annual } \\
\text { Growth (\%) }\end{array}$ & Difference & t-statistic & $\begin{array}{c}\text { Probability of } \\
\text { t(one-sided) }\end{array}$ \\
\hline Republican First Terms & 3.59 & -1.16 & -1.23 & .117 \\
All Democratic Years & 3.80 & -1.37 & -1.90 & .032 \\
Democratic Second Terms & 4.14 & -1.71 & -1.83 & .037 \\
Democratic Second Terms Minus Truman* & 3.97 & -1.54 & -1.80 & .041 \\
All Other Years & 3.77 & -1.34 & -1.89 & .032 \\
\hline
\end{tabular}

* We omit Truman's second term in this comparison, as real GDP growth hit $13.4 \%$ in 1950 — the first year of the Korean War-easily a postwar high.

8. In Tables 4 and 5 we count George H. W. Bush's sole term as a Republican second term, as he followed upon another Republican term (Ronald Reagan's second). 
TABLE 5

Mean Annual Unemployment Rate, 1949-2009

Republican Second Term Years $(6.25 \%)$ versus Other Years

\begin{tabular}{lcccc}
\hline & $\begin{array}{c}\text { Mean Annual } \\
\text { Unemployment } \\
\text { Rate (\%) }\end{array}$ & Difference & t-statistic & $\begin{array}{c}\text { Probability of } \\
\text { t(one-sided) }\end{array}$ \\
\hline Republican First Terms & 6.23 & 0.02 & 0.03 & .487 \\
All Democratic Years & 4.89 & 1.36 & 3.77 & $<.001$ \\
Democratic Second Terms & 4.14 & 2.11 & 5.64 & $<.0001$ \\
Democratic Second Terms Minus Truman* & 4.16 & 2.09 & 4.99 & $<.0001$ \\
All Other Years & 5.32 & 0.93 & 2.42 & .009 \\
\hline
\end{tabular}

* We omit Truman's second term from this comparison, as unemployment hit $2.93 \%$ in 1953 - the third year of the Korean War-a postwar low.

TABLE 6

Growth of Real Gross Domestic Product (GDP) and Real Disposable Personal Income per capita, 1949-2009

\begin{tabular}{lrr}
\hline & Model 1 & Model 2 \\
& Real GDP (\% Growth) & Real DPI (\% Growth) \\
\hline Democratic PRESIDENT & $1.04 * *(.38)$ & $.82 * * *(.35)$ \\
QTROUGH & $-.06 * * *(.01)$ & $-.02 *(.01)$ \\
QPEAK & $.04 * * *(.01)$ & $.01(.01)$ \\
Oil Price (Lagged) & $-3.51 * * *(.87)$ & $-1.28 *(.80)$ \\
WAR & $.37(.33)$ & $.29(.30)$ \\
ELECTION & $.26(.28)$ & $.40 *(.26)$ \\
Constant & $4.04 * * *(.41)$ & $2.25 * * *(.38)$ \\
Regress $\mathrm{R}^{2}$ & .20 & .06 \\
Total $\mathrm{R}^{2}$ & .80 & .66 \\
\hline
\end{tabular}

* statistically significant at .10 level, ** at .05 level, *** at .01 level.

the results here and in Table 7 are computed with a Yule-Walker correction for autocorrelation up through the fourth order.

All variables in both models of Table 6 carry the expected signs. The economic control measures are highly significant in Model 1 but not in Model 2. The estimated coefficient on the Democratic PRESIDENT variable in Model 1 indicates that annual real GDP growth was about 1.0 percentage point higher under Democratic presidents, even in the face of effective controls for the ups and downs of the business cycle. Real disposable personal income per capita grew a similar $.82 \%$ per year faster under Democratic presidents, although the weak effects for QTROUGH and QPEAK in Model 2 preclude confidence that the effects of the business cycle have been adequately controlled.

Table 7 presents the results of the spline regressions on the levels of real GDP and real disposable personal income per capita, and the civilian unemployment rate (Models 3, 4, and 5). The economic control variables denoting the periods of expansion and 


\section{TABLE 7}

Levels of Real Gross Domestic Product (GDP), Real Disposable Personal Income (DPI) per capita, and Unemployment Rate, 1949-2009

\begin{tabular}{|c|c|c|c|}
\hline & $\begin{array}{l}\text { Model } 3 \\
\text { Real GDP }\end{array}$ & $\begin{array}{c}\text { Model } 4 \\
\text { Real DPI }\end{array}$ & $\begin{array}{c}\text { Model } 5 \\
\text { Unemployment Rate (\%) }\end{array}$ \\
\hline Democratic PRESIDENT & $99.4 * *(45.9)$ & $74.3(123.2)$ & $-1.43 * * *(.27)$ \\
\hline Oil Price (lagged) & $-17.2(84.5)$ & $294.7(318.7)$ & $.83 * *(.51)$ \\
\hline WAR & $-11.3(21.8)$ & $-52.7(85.0)$ & $.06(.13)$ \\
\hline ELECTION & $-4.7(8.8)$ & $59.7 * *(34.1)$ & $-.05(.05)$ \\
\hline Peak1948:4 & $.34 * * *(.09)$ & $.72 * * *(.22)$ & $-.003 * * *(.0004)$ \\
\hline Trough1949:4 & $-.53 * * *(.16)$ & $-1.17 * * *(.39)$ & $.006 * * *(.0008)$ \\
\hline Peak1953:2 & $.98 * *(.44)$ & $2.45 * *(1.02)$ & $-.01 * * *(.002)$ \\
\hline Trough1954:2 & $-1.09 * *(.51)$ & $-2.78 * * *(1.15)$ & $.02 * * *(.003)$ \\
\hline Peak1957:3 & $2.27 * *(1.01)$ & $4.43 * *(2.25)$ & $-.03 * * *(.005)$ \\
\hline Trough1958:2 & $-2.74 * *(1.22)$ & $-4.79 * *(2.71)$ & $.03 * * *(.006)$ \\
\hline Peak1960:2 & $1.95 * *(.83)$ & $3.16 * *(1.81)$ & $-.02 * * *(.004)$ \\
\hline Trough1961:1 & $-1.22 * *(.49)$ & $-2.13 * *(1.05)$ & $.01 * * *(.002)$ \\
\hline Peak1969:4 & $.78 * * *(.21)$ & $2.01 * * *(.41)$ & $-.005 * * *(.0009)$ \\
\hline Trough1970:4 & $-1.15 * * *(.30)$ & $-3.00 * * *(.59)$ & $.007 * * *(.001)$ \\
\hline Peak1973:4 & $1.35 * * *(.33)$ & $3.47 * * *(.67)$ & $-.008 * * *(.001)$ \\
\hline Trough1975:1 & $-1.13 * * *(.28)$ & $-2.79 * * *(.58)$ & $.006 * * *(.001)$ \\
\hline Peak1980:1 & $1.20(1.82)$ & $1.58(4.29)$ & $.003(.01)$ \\
\hline Trough1980:3 & $-.81(2.92)$ & $1.18(6.93)$ & $-.01(.02)$ \\
\hline Peak1981:3 & $-.20(1.54)$ & $-3.64(3.64)$ & $.01 *(.008)$ \\
\hline Trough1982:4 & $-.07(.40)$ & $1.21 *(.92)$ & $-.002(.002)$ \\
\hline Peak1990:3 & $1.15 * * *(.17)$ & $1.93 * * *(.35)$ & $-.006 * * *(.0008)$ \\
\hline Trough1991:1 & $-1.12 * * *(.17)$ & $-1.86 * * *(.34)$ & $.006 * * *(.0007)$ \\
\hline Peak2001:1 & $.27 * *(.14)$ & $-.51 * *(.28)$ & $-.002 * * *(.0006)$ \\
\hline Trough2001:4 & $-.27 * *(.15)$ & $.63 * *(.32)$ & $.003 * * *(.0006)$ \\
\hline Peak2007:4 & $-1.59 * * *(.41)$ & $-2.09 * *(1.05)$ & $.007 * * *(.002)$ \\
\hline Trough2009:2 & $15.60 * * *(3.45)$ & $7.97(10.93)$ & $-.04 * *(.02)$ \\
\hline Constant & $1737.0 * * *(72.9)$ & $8581.0 * * *(173.0)$ & $7.48 * * *(.38)$ \\
\hline Regress $\mathrm{R}^{2}$ & .99 & .99 & .89 \\
\hline Total $\mathrm{R}^{2}$ & .99 & .99 & .98 \\
\hline
\end{tabular}

* statistically significant at .10 level, ** at .05 level, *** at .01 level.

contraction from 1949:1 to 2009:4 are mostly strongly significant with the exception of the years from 1980 to 1982 . With a few exceptions, mostly during those same years, their signs alternate from positive to negative as the dependent variables rose (fell) during economic expansions and fell (rose) during economic contractions. The $R^{2}$ values for all three models are very high for models that lack a lagged value of the dependent variable. These results provide confidence that these models have captured the ups and downs of the business cycle.

With a Democrat in the White House, real GDP was higher by $\$ 99$ billion $(p<.05)$. Although the great increase in real GDP from 1949 to 2009 makes interpretation difficult, $\$ 99$ billion is approximately $1.7 \%$ of the median value of real GDP over that period. The civilian unemployment rate was 1.4 points lower under Democratic 
presidents $(p<.01)$. The $-1.4 \%$ estimate in Model 5 and the $+1.0 \%$ estimate in Model 1 of Table 6 are virtually identical to Bartels' estimates (2008).

The results for the Democratic PRESIDENT variable in the models for the growth and level of real disposable personal income per capita (Models 2 and 4) must be judged inconclusive. The strongly significant PRESIDENT variable in Model 2 indicates that real disposable income rose faster under Democratic presidents. But the economic control variables QTROUGH and QPEAK are not significant at the customary .05 level in Model 2. In Model 4, where the spline variables control for the business cycle more effectively than QTROUGH and QPEAK do in Model 2, the Democratic PRESIDENT variable has a sizable and positive coefficient but is statistically insignificant. Hence we cannot say that Democratic presidents positively impacted real disposable personal income per capita once the ups and downs of the business cycle are adequately controlled for.

The WAR variable is insignificant in all five models of Tables 6 and 7, and has the wrong sign in Models 3 and 4. The ELECTION variable was insignificant in the models for growth and level of GDP and for unemployment (Models 1, 3, and 5). Interestingly, however, in the models for growth and level of disposable personal income (Models 2 and 4), the ELECTION variable was significant at the .10 and .05 levels. These results suggest the intriguing possibility that presidents have learned, as the election literature has reported, that their reelection chances depend heavily on the behavior of real disposable personal income in the election year (e.g., Bartels and Zaller 2001) and have successfully increased that measure in election years. The results for the separate dummy variables denoting presidential election years with Republican and Democratic presidential incumbents were, however, insignificant; we omit these insignificant results in Tables 6 and 7.9

There were no consistent, significant, and interpretable results for variables expressing Democratic control of Congress or interaction effects between a Democratic Congress and a Democratic president, and those results are omitted here. ${ }^{10}$

Figure 2 shows graphically the results of the spline regression on the unemployment rate between 1949 and 2009 (Model 5 of Table 7). The vertical lines mark the start and end dates of recessions, which we used to define the spline variables in Table 7. The observed values of the unemployment rate are shown with small asterisks; the solid line represents the model's predictions. The figure demonstrates clearly the decline in the unemployment rate during the several relatively long periods of economic expansion,

9. One might wonder why real oil prices exert such a strong negative effect on real GDP growth in Model 1 but not on the level of real GDP in Model 3. One possibility is that the spline, or economic control variables in Model 3 "explain" the level of real GDP so well, producing an $R^{9}$ of .99 , that the regression attributes the explanatory power of the oil variable to the closely related spline variables. Model 3 still attributes significance to the Democratic PRESIDENT variable, however, because that variable is less correlated with the spline variables than oil prices are. Real oil prices drifted downward under Democrats Truman, Kennedy and Johnson, rose sharply under Carter, and fluctuated under Clinton.

10. These variables were mostly insignificant, with most of the few significant results reflecting anomalies in the data. For instance, the combination of a Republican president, a Democratic House of Representatives, and a Republican Senate appeared to be associated with higher unemployment but mainly because the U.S. experienced that combination only once: in the early to mid-1980s, when unemployment was high for other reasons. 
54 PRESIDENTIAL STUDIES QUARTERLY / March 2012

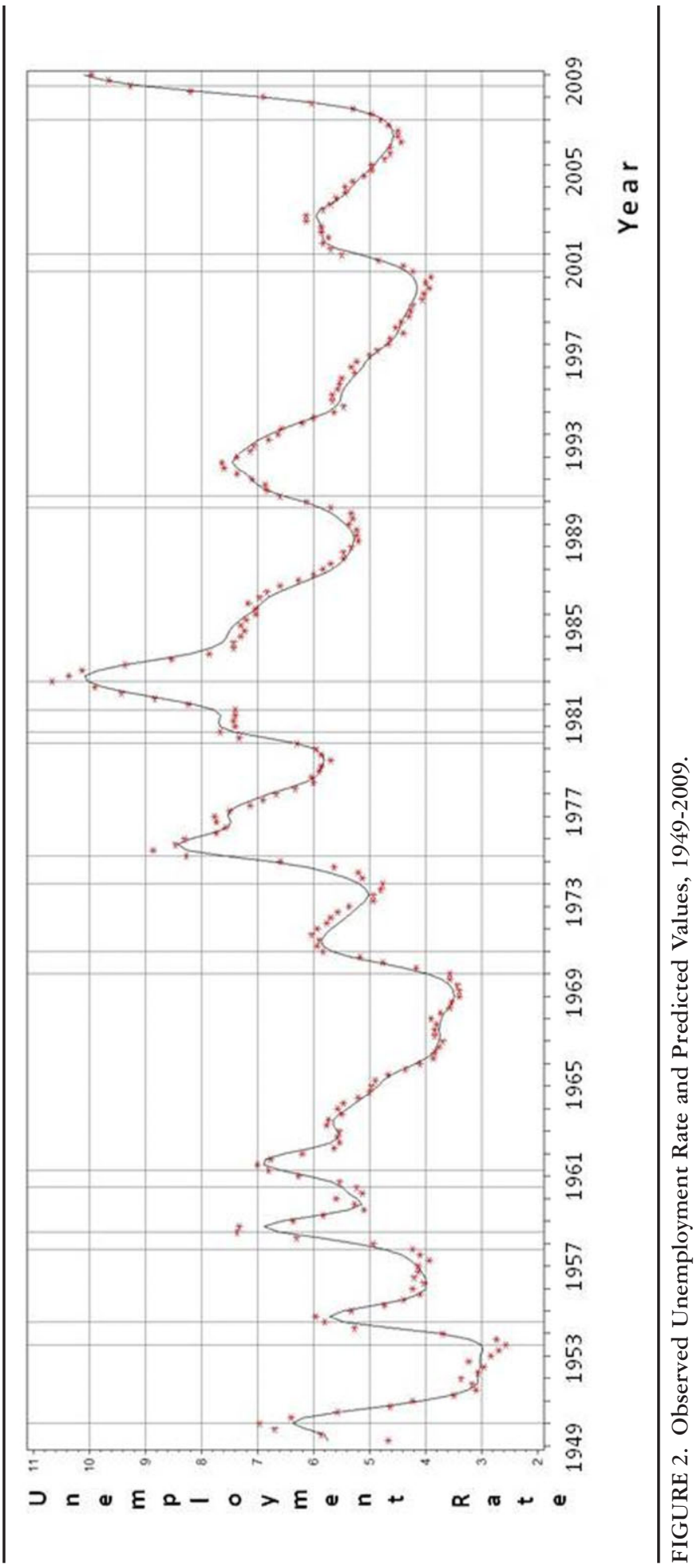


most notably those of 1961 to 1969,1982 to 1990 , and 1991 to 2001, and the rise in unemployment during the several recessions such as 1953 to 1954,1973 to 75 , and 1981 to 1982. It also demonstrates vividly the ability of the spline technique to capture the ups and downs of the business cycle and leaves little doubt that we have done so.

Figure 3 is a simple plot of the unemployment rate during each presidency from 1949 to 2009. It clearly demonstrates that unemployment fell over the course of each Democratic presidency but Carter's and rose during each Republican presidency but Reagan's. Three of the four lows in unemployment took place near the ends of three Democratic presidencies - those of Truman, Kennedy-Johnson, and Clinton. The fourth low point in unemployment took place near the end of Eisenhower's first term from 1955 to 1957 , before unemployment then ratcheted upward in his second term. The figure thus provides intuitive visual confirmation of our result in Model 5.

To summarize, we have used time in three ways to control for the alleged impact of the business cycle on the comparative economic records of Democratic and Republican presidents-by focusing on Republican second terms in Tables 4 and 5, by controlling for the point in the business cycle with the number of quarters since the last peak and last trough of economic activity in Table 6, and by employing separate "spline" variables for each economic expansion and contraction in the post-World War II era in Table 7. Our results for real GDP and unemployment confirm Bartels' findings. And we derived these results, as explained above, while running considerable risks, more so than previous scholars in at least one respect, that our methods themselves would negate the likelihood of statistically significant results.

\section{Discussion}

Our results imply that U.S. presidents are more the masters of their economic and political fates than is commonly supposed. Presidents may be the products of the business cycle, with Democrats taking the White House at times of high unemployment and low inflation, and Republicans winning in the opposite circumstances (Table 1), but they are not just captives of the business cycle once in office. Democratic and Republican presidents do not simply board upward and downward escalators. "Democratic business cycles" appear more robust than "Republican business cycles," with economic growth and real output higher, and unemployment lower, over the cycle when a Democrat sits in the White House.

A finding more freighted with partisan political implications is hard to imagine. There may be no consensus anytime soon about the validity of these results for that reason. in addition to the usual scholarly uncertainties (which include in this case the inconclusive results for real disposable personal income).

If further studies confirm our results for output and unemployment, an obvious question for further research is how Democratic presidents produce stronger economic records than Republicans. That question will almost certainly be very difficult to answer. After several decades of theory and empirical research, economists are not in complete agreement about the factors governing the business cycle (Romer 2008), and there is no 


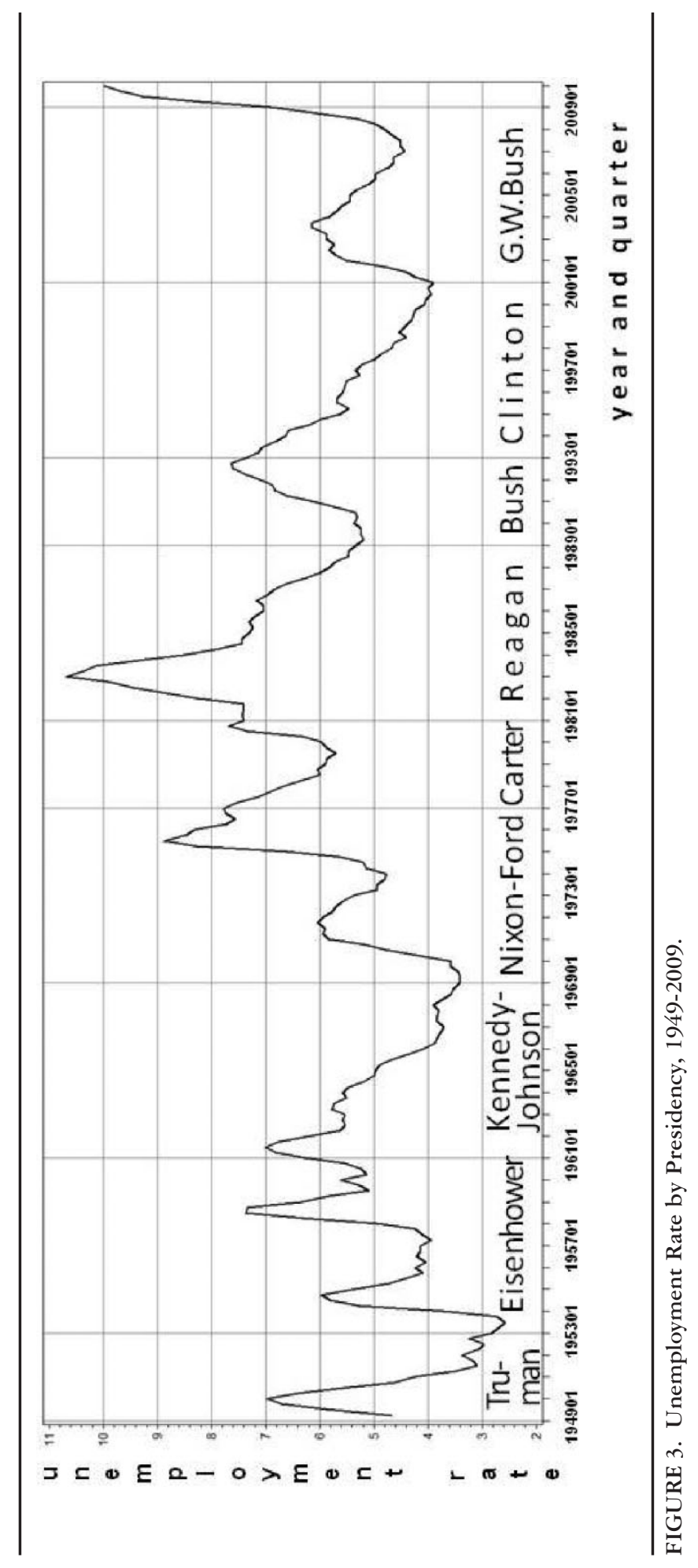


reason to expect a quick consensus on a question so obviously pregnant with partisan implications. Anyone who could convincingly demonstrate that one party regularly produced better economic results than another, and how that party did so, would surely merit consideration for a Nobel Prize in economics.

A more immediate question for political scientists is why Democrats have lost nine of the last fifteen presidential elections given the apparent superiority of their economic records. Bartels gives several answers, most of them with disturbing implications for democratic theory and practice: white Southern voters have moved to the Republican column in reaction to Democratic civil rights policies; voters respond to higher Republican presidential campaign expenditures; voters at all income levels rather inexplicably base their votes on the economic welfare of the upper-income strata who do relatively well (or less poorly) under Republican presidents; and myopic voters reward Republican presidents for the superior Republican record of income growth in presidential election years, the one year out of four when incomes grow faster under Republican presidents than under Democrats (Chapter 4).

We have not tried to replicate these findings and cannot speak directly to them. ${ }^{11}$ We can, however, suggest three additional explanations for the Democrats' difficulties, two of which are economic in nature. The first economic hypothesis is that Democrats' electoral woes spring from the conjunction of the business and presidential election cycles. The average postwar economic expansion lasted 20.2 quarters, or almost exactly five years, with new Democratic administrations taking office an average of one year into these expansions (Table 1). The next recession is then "due" four years later, just when the Democratic administration is seeking a second term. The explanatory power of this hypothesis appears, however, to be modest. Of the three presidential election years from 1949 to 2009 in which a Democratic administration sought a second term-1964, 1980, and 1996-economic growth was clearly declining in only one: 1980, when the 5 to $6 \%$ annual GDP growth of Jimmy Carter's first two years had given way to a recession that helped drive Carter from office.

A second economic hypothesis is that inflation was, after all, higher or at least accelerating under Democratic presidents and that this factor cost the Democrats at least two of the nine presidential elections they lost from 1952 to 2008. On the one hand, the literature on "economic voting" by U.S. voters is vast and quite sophisticated, and it attributes "little or no electoral importance" to the rate of inflation (Hibbs 2006, 3; see also Lewis-Beck and Stegmaier 2007). But for two reasons we think inflation may be worth a second look.

First, Bartels reports in a footnote that multivariate analyses produce "some statistical evidence of higher inflation rates under Democratic presidents" (2008, 49n36). Second, the number of presidential elections we are considering is still rather small (15),

11. The insignificant results for the separate dummy variables denoting presidential election years with Republican and Democratic presidential incumbents might seem at first glance to contradict Bartels'(2008) claim that incomes grew faster in presidential election years with Republican incumbents. But for two reasons they do not. First, our test was a test for a spike in growth around election time rather than the more gradual changes in growth over four years that Bartels documents. Second, Bartels' claim is essentially that the business cycle favors Republican incumbents, and we have controlled for the business cycle. 
and the absolute difference in electoral victories is much smaller (nine versus six, for a difference of three). The reversal of even two Democratic losses attributable to inflation would have tilted the balance slightly in the Democrats' favor (eight Democratic victories to seven for the Republicans).

Inflation may have spelled the Democrats' defeat in both 1968 and 1980. By 1968 the rate of inflation during the Kennedy-Johnson years had risen from around $1 \%$ annually in 1961 to 1964 to nearly 5\%. This accelerating inflation was enough to impel President Lyndon Johnson and a Democratic Congress to enact an antiinflationary tax increase just four months before Election Day (Romer and Romer 2008 , 48-49). Although a mere $9 \%$ of the public chose "the high cost of living, taxes" as the nation's worst problem that year (Gallup 1972, 2151), a switch of only $0.5 \%$ of the two-party vote from Richard Nixon to Hubert Humphrey would have wiped out Nixon's popular vote margin if not his Electoral College majority (American Presidency Project 2011).

Inflation clearly contributed mightily to President Jimmy Carter's defeat in 1980, after the Consumer Price Index rose at record rates of 13.3 and $12.4 \%$ in 1979 and 1980, respectively. ${ }^{12}$ The quantitative voting literature may attribute this defeat to the sharp recession that hit in the spring of 1980, but that downturn was itself the product of inflation, which eroded consumer purchasing power, brought Paul Volcker and a tight monetary policy to the Federal Reserve, and prompted the adoption of consumer credit controls that sharply curtailed the purchase of consumer durables in early 1980 (Biven 2002, 237-52).

A third, noneconomic explanation for the Democrats' electoral difficulties is that noneconomic factors have hurt the Democrats badly: Korea in 1952, Vietnam in 1968, the Electoral College in 2000, and the national security issue in 2004.

Even without these additional hypotheses for investigation, the foregoing paragraphs make clear that political scientists and economists studying presidential economic policies have plenty to do.

\section{References}

Alesina, Alberto, and Howard Rosenthal. 1995. Partisan Politics, Divided Government, and the Economy. Cambridge: Cambridge University Press.

American Presidency Project. 2011. Presidential Elections Data: 1968. http://www.presidency. ucsb.edu/showelection.php? year=1968 (accessed December 15, 2011).

Bartels, Larry M. 2008. Unequal Democracy: The Political Economy of the New Gilded Age. Princeton, NJ: Princeton University Press.

Bartels, Larry M., and John Zaller. 2001. "Presidential Vote Models: A Recount.” PS: Political Science and Politics 34 (March): 8-20.

Bernanke, Ben S., and Mark Gertler. 1995. "Inside the Black Box: The Credit Channel of Monetary Policy Transmission." Journal of Economic Perspectives 9 (Fall): 27-48.

Biven, W. Carl. 2002. Jimmy Carter's Economy: Policy in an Age of Limits. Chapel Hill: University of North Carolina Press.

12. The Consumer Price Index in use at the time overstated the rate of inflation by perhaps as much as $50 \%$, but there is little indication that noneconomists realized it then (Biven 2002, 192). 
Blanchard, Olivier, and Roberto Perotti. 2002. "An Empirical Characterization of the Dynamic Effects of Changes in Government Spending and Taxes on Output." Quarterly Journal of Economics 117 (November): 1329-68.

Campbell, James E. 2011. "The Economic Records of the Presidents: Party Differences and Inherited Economic Conditions." Forum 9 (1): 1-29.

Elmendorf, Douglas W. 2009. "Letter to the Honorable Charles E. Grassley," March 2. http://www. cbo.gov/ftpdocs/100xx/doc10008/03-02-Macro_Effects_of_ARRA.pdf.

Elmendorf, Douglas W., and Jason Furman. 2008. "If, When, How: A Primer on Fiscal Stimulus." Hamilton Project Strategy Paper, January 10. http://www.brookings.edu/papers/2008/0110_ fiscal_stimulus_elmendorf_furman.aspx.

Elmendorf, Douglas W., and David L. Reifschneider. 2002. "Short-Run Effects of Fiscal Policy with Forward-Looking Financial Markets.” National Tax Journal 55 (September): 357-86.

Gallup, George H. 1972. The Gallup Poll: Public Opinion 1935-1971, vol. 3. New York: Random House.

Gordon, Robert J. 2009. Macroeconomics. Boston: Pearson.

Hibbs, Douglas A. 1977. "Political Parties and Macroeconomic Policy." American Political Science Review 71 (December): 1467-87.

1987. The American Political Economy. Cambridge, MA: Harvard University Press.

. 2006. "Voting and the Macroeconomy." In Oxford Handbook of Political Economy, eds. Barry R. Weingast and Donald A. Wittman. Oxford: Oxford University Press, 565-86.

Lewis-Beck, Michael S., and Mary Stegmaier. 2007. "Economic Models of Voting." In Oxford Handbook of Political Behavior, eds. Russell J. Dalton and Hans-Dieter Klingemann. Oxford: Oxford University Press, 518-37.

Marsh, Lawrence C., and David R. Cormier. 2002. Spline Regression Models. Thousand Oaks, CA: Sage.

National Bureau of Economic Research. 2011. "US Business Cycle Expansions and Contractions." http://www.nber.org/cycles.html (accessed December 15, 2011).

Nordhaus, William. 1975. "The Political Business Cycle." Review of Economic Studies 42 (April): 169-90.

Romer, Christina D. 2008. "Business Cycles." The Concise Encyclopedia of Economics. Indianapolis, IN: Liberty Fund.

Romer, Christina D., and David H. Romer. 2008. "A Narrative Analysis of Postwar Tax Changes." http://elsa.berkeley.edu/ cromer/nadraft1108.pdf (accessed December 15, 2011).

Yang, Shu-Chun S. 2009. “A Chronology of Federal Income Tax Policy: 1947-2009.” http://ssrn.com/ abstract $=1020679$. 